\title{
Unruptured Intracranial Aneurysm: Screening, Prevalence and Risk Factors
}

\author{
Bum-soo Kim, MD \\ Department of Radiology, Seoul St. Mary's Hospital, College of Medicine, The Catholic University of Korea, Seoul, Korea
}

Subarachnoid hemorrhage (SAH) due to ruptured intracranial aneurysm is life-threatening, and screening for unruptured intracranial aneurysm (UIA) in selected patients and providing treatment before rupture of selected aneurysms are medically and economically beneficial. Therefore, screening for UIA must be tailored to specific populations in order to balance the prevalence and risk of UIA, cost-effectiveness of screening tests, and the availability of effective and safe treatment. ${ }^{1,2}$ Of these, estimating the prevalence and risk factor of UIA by epidemiological study is methodologically challenging, requiring an optimal cohort for prospective studies with a large amount of data. ${ }^{3}$

In the last issue, Kim and colleagues ${ }^{4}$ evaluated the prevalence (3.77\%) and risk factors (female predominance and hypertension) of UIAs from healthy individuals who underwent brain magnetic resonance angiography using $3 \mathrm{~T}$ magnetic resonance imaging as part of a routine health examination. There have been several other studies evaluating the prevalence and risk factors of UIA in the literature. The studies were variable with regards to the population studied, indication for imaging, and method of detection (Table 1). ${ }^{4-13}$ The reported prevalence of UIA in the literature ranged $1.8-8.8 \%$, and was $3.2 \%$ according to combined results from a systematic review and meta-analyses, ${ }^{10}$ which was also similar to the result (3.77\%) from Kim et al. ${ }^{4}$ In evaluating the risk factors of UIA, it was more common in women, older age, smokers, patients with hypertension, autosomal dominant polycystic kidney disease (ADPKD), or in individuals with family history of intracranial aneurysm of SAH. Consequently, Korean Clinical Practice Guidelines for UIA currently recommended that UIA should be screened according to the following three categories; 1) patients who have 2 or more first-degree relatives with an intracranial aneurysm; 2) patients with ADPKD; and 3) regular screening tests for new aneurysms for patients previously treated with aneurysmal SAH. Although the current guidelines do not support widespread screening for intracranial aneurysms in the general population, additional screening may be considered in patients with other genetic or medical conditions associated with intracranial aneurysms. ${ }^{14}$

Recently, according to the data from Korean National Health Insurance Service (NHIS), the number of treatments for UIA has increased because of the increased detection rate as well as increase in number of hospitals capable

\section{Correspondence to: Bum-soo Kim, MD \\ Department of Radiology, Seoul St. Mary's Hospital, College of Medicine, The Catholic University of Korea, 222 Banpo-daero, Seocho-gu, Seoul 06591, Korea \\ Tel: +82-2-2258-9639 \\ Fax: +82-2-599-6771 \\ E-mail:bkim.neurorad@gmail.com}

Received: October 5, 2021

Revised: October 14, 2021

Accepted: October 17, 2021
Copyright $\odot 2021$ Korean Society of Interventional Neuroradiology

This is an Open Access article distributed under the terms of the Creative Commons Attribution Non-Commercial License (http://creativecommons.org/licenses/by-nc/4.0) which permits unrestricted non-commercial use, distribution, and reproduction in any medium, provided the original work is properly cited.

pISSN 2093-9043 eISSN 2233-6273 
Table 1. Summary of prevalence and risk factor in occurrence of unruptured intracranial aneurysm in the literature

\begin{tabular}{|c|c|c|c|c|c|c|}
\hline Author (y) & $\begin{array}{c}\text { Total } \\
\text { number }\end{array}$ & Study cohort & Prevalence & Risk factor & Modality & Country \\
\hline Kim et al. $(2021)^{4}$ & 2,118 & $\begin{array}{l}\text { Single center (health } \\
\text { check) }\end{array}$ & $3.8 \%$ & Female, hypertension & TOF MRA (3T) & Korea \\
\hline Cras et al. $(2020)^{5}$ & 5,841 & Population-based & $2.3 \%$ & $\begin{array}{l}\text { Female, hypertension, } \\
\text { smoking }\end{array}$ & TOF MRA (1.5T) & Netherland \\
\hline Imaizumi et al. (2018) & 4,032 & $\begin{array}{l}\text { Single center (health } \\
\text { check) }\end{array}$ & $4.32 \%$ & Female, older age & TOF MRA (3T) & Japan \\
\hline Li et al. $(2014)^{7}$ & 3,993 & Single center (patients) & $8.8 \%$ & Female, older age & CE MRA (1.5T) & China \\
\hline Park et al. $(2014)^{8}$ & 18,237 & $\begin{array}{l}\text { Single center (health } \\
\text { check \& patients) }\end{array}$ & $1.8 \%$ & Female, older female & TOF MRA (1.5T) & Korea \\
\hline Li et al. $(2013)^{9}$ & 4,813 & $\begin{array}{l}\text { Community-based } \\
\text { cross sectional } \\
\text { survey }\end{array}$ & $7.0 \%$ & Female, older age & TOF MRA (3T) & China \\
\hline Vlak et al. $(2011)^{10}$ & 94,912 & $\begin{array}{l}\text { Systematic review and } \\
\text { meta-analysis }\end{array}$ & $3.2 \%$ & $\begin{array}{l}\text { Female, older age, ADPKD, } \\
\text { family history of SAH, } \\
\text { pituitary adenoma, } \\
\text { atherosclerosis, Japan, } \\
\text { Finland }\end{array}$ & CTA, MRA, DSA & 21 countries \\
\hline Jeon et al. $(2011)^{11}$ & 3,049 & Single center (patients) & $5 \%$ & Female & TOF MRA (3T) & Korea \\
\hline Iwamoto et al. (1999) ${ }^{12}$ & 1,230 & $\begin{array}{l}\text { Community-based (30 } \\
\text { years) }\end{array}$ & $4.6 \%$ & Female & Autopsy & Japan \\
\hline Ujiie et al. $(1993)^{13}$ & 1,612 & & $2.7 \%$ & Older female & DSA & Japan \\
\hline
\end{tabular}

TOF, time-of-flight; MRA, magnetic resonance angiography; 3T, 3-tesla; 1.5T, 1.5-tesla; CE, contrast enhanced; CTA, computed tomography angiography; DSA, digital subtraction angiography; ADPKD, autosomal dominant polycystic kidney disease; SAH, subarachnoid hemorrhage.

of performing embolization of UIA. ${ }^{15}$ In studies analyzing data from a cohort of 1 million people from the Korean NHIS, the crude incidence of UIA increased steadily from 29.6 per 100,000 person-years in $2008^{18}$ to 90.0 per 100,000 person-years in $2016 .{ }^{17}$ It is believed that this is due to an increase in the number of asymptomatic cerebral aneurysms discovered through screening rather than an increase in the number of development of cerebral aneurysms. Meanwhile, the incidence of ruptured intracranial aneurysm has decreased, which may be due to an increase in the treatment of UIA and improved management of hypertension through health screening. ${ }^{16}$ The worldwide incidence of SAH also declined between 1980 and 2010 in Europe, Asia and North America, in parallel with a global decline in prevalence of hypertension and smoking, ${ }^{17}$ which is also in good contrast with an increasing rate of diagnosis of UIA. However, the same study also showed increased incidence of SAH in Japan, ${ }^{17}$ and there is another report which showed no decline of incidence of SAH in Korean. ${ }^{18}$ Therefore, the regional or ethnic difference should also be considered for elucidating the effective relationship between the active screening and treatment of UIA, and their preventive effect for $\mathrm{SAH}$.

\section{Fund}

None.

\section{Conflicts of Interest}

BK has been the Associate Editor of the Neurointervention since 2020. No potential conflict of interest relevant to this article was reported.

\section{ORCID}

Bum-soo Kim: https://orcid.org/0000-0002-3870-6813

\section{REFERENCES}

1. Jeong HW, Seo JH, Kim ST, Jung CK, Suh SI. Clinical practice guideline for the management of intracranial aneurysms. Neurointervention 2014;9:63-71 
2. Thompson BG, Brown RD Jr, Amin-Hanjani S, Broderick JP, Cockroft KM, Connolly ES Jr, et al.; American Heart Association Stroke Council, Council on Cardiovascular and Stroke Nursing, and Council on Epidemiology and Prevention; American Heart Association; American Stroke Association. Guidelines for the management of patients with unruptured intracranial aneurysms: a guideline for healthcare professionals from the American Heart Association/American Stroke Association. Stroke 2015;46:23682400

3. Korja M, Kaprio J. Controversies in epidemiology of intracranial aneurysms and SAH. Nat Rev Neurol 2016;12:50-55

4. Kim JH, Lee KY, Ha SW, Suh SH. Prevalence of unruptured intracranial aneurysms: a single center experience using $3 T$ brain MR angiography. Neurointervention 2021;16:117-121

5. Cras TY, Bos D, Ikram MA, Vergouwen MDI, Dippel DWJ, Voortman $T$, et al. Determinants of the presence and size of intracranial aneurysms in the general population: the Rotterdam study. Stroke 2020;51:2103-2110

6. Imaizumi Y, Mizutani T, Shimizu K, Sato Y, Taguchi J. Detection rates and sites of unruptured intracranial aneurysms according to sex and age: an analysis of MR angiography-based brain examinations of 4070 healthy Japanese adults. J Neurosurg 2018;130:573-578

7. Li J, Shen B, Ma C, Liu L, Ren L, Fang Y, et al. 3D contrast enhancement-MR angiography for imaging of unruptured cerebral aneurysms: a hospital-based prevalence study. PLoS One 2014;9:e114157

8. Park S, Lee DH, Ryu CW, Pyun HW, Choi CG, Kim SJ, et al. Incidental saccular aneurysms on head MR angiography: 5 years' experience at a single large-volume center. J Stroke 2014;16:189-194

9. Li MH, Chen SW, Li YD, Chen YC, Cheng YS, Hu DJ, et al. Prevalence of unruptured cerebral aneurysms in Chinese adults aged 35 to 75 years: a cross-sectional study. Ann Intern Med
2013;159:514-521

10. Vlak MH, Algra A, Brandenburg R, Rinkel GJ. Prevalence of unruptured intracranial aneurysms, with emphasis on sex, age, comorbidity, country, and time period: a systematic review and meta-analysis. Lancet Neurol 2011;10:626-636

11. Jeon TY, Jeon P, Kim KH. Prevalence of unruptured intracranial aneurysm on MR angiography. Korean J Radio/ 2011;12:547-553

12. I wamoto H, Kiyohara Y, Fujishima M, Kato I, Nakayama K, Sueishi $K$, et al. Prevalence of intracranial saccular aneurysms in a Japanese community based on a consecutive autopsy series during a 30-year observation period. The Hisayama study. Stroke 1999;30:1390-1395

13. Ujiie H, Sato K, Onda H, Oikawa A, Kagawa M, Takakura K, et al. Clinical analysis of incidentally discovered unruptured aneurysms. Stroke 1993;24:1850-1856

14. Toth G, Cerejo R. Intracranial aneurysms: review of current science and management. Vasc Med 2018;23:276-288

15. Lee SU, Kim T, Kwon OK, Bang JS, Ban SP, Byoun HS, et al. Trends in the incidence and treatment of cerebrovascular diseases in Korea: part I. Intracranial aneurysm, intracerebral hemorrhage, and arteriovenous malformation. J Korean Neurosurg Soc 2020:63:56-68

16. Lee JH, Yang DH, Park HS, Cho Y, Jun JE, Park WH, et al.; HYpertension-Diabetes Daegu Initiative Study Investigators. Incidence of hypertension in Korea: 5-year follow-up study. J Korean Med Sci 2011;26:1286-1292

17. Etminan N, Chang HS, Hackenberg K, de Rooij NK, Vergouwen MDI, Rinkel GJE, et al. Worldwide incidence of aneurysmal subarachnoid hemorrhage according to region, time period, blood pressure, and smoking prevalence in the population: a systematic review and meta-analysis. JAMA Neurol 2019;76:588-597

18. Suh SH. The annual trends between neurointerventional and neurosurgical procedures in Korea: analysis using HIRA data from 2010 to 2016. Neurointervention 2017;12:77-82 